\title{
The era of sustainable agricultural development in Africa: Understanding the benefits and constraints
}

by Adenle, A.A., Hossein, A. and Manning, L.

Copyright, Publisher and Additional Information: This is the author accepted manuscript. The final published version (version of record) is available online via Taylor \& Francis Please refer to any applicable terms of use of the publisher.

DOI: http://dx.doi.org/10.1080/87559129.2017.1300913

Harper Adams

University

Adenle, A.A., Hossein, A. and Manning, L. 2017. The era of sustainable agricultural development in Africa: Understanding the benefits and constraints, Food Reviews International. 


\section{The era of sustainable agricultural development in Africa: Understanding the benefits and constraints}

\section{Ademola A. Adenle, Hossein Azadi \& Louise Manning}

To cite this article: Ademola A. Adenle, Hossein Azadi \& Louise Manning (2017): The era of sustainable agricultural development in Africa: Understanding the benefits and constraints, Food Reviews International, DOI: 10.1080/87559129.2017.1300913

To link to this article: http://dx.doi.org/10.1080/87559129.2017.1300913

Accepted author version posted online: 08 Mar 2017.

Submit your article to this journal ¿

Q View related articles $₫$

View Crossmark data $\circlearrowright$ 


\title{
The era of sustainable agricultural development in Africa: Understanding the benefits and constraints
}

\author{
Ademola A. Adenle ${ }^{\text {ab* }}$, Hossein Azadi ${ }^{\text {cd }}$, Louise Manning ${ }^{\text {ef }}$ \\ ${ }^{a}$ School of Global Environmental Sustainability, Colorado State University, USA \\ ${ }^{\mathrm{b}}$ United Nations University-Institute for Advanced Studies of Sustainability (UNU-IAS), Japan \\ ${ }^{c}$ Department of Geography, Ghent University, Belgium \\ ${ }^{\mathrm{d}}$ Economics and Rural Development, University of Liège, Belgium \\ eSchool of Agriculture, Food and Environment, Royal Agriculture University, UK \\ ${ }^{\mathrm{f} S c h o o l ~ o f ~ F o o d ~ S c i e n c e ~ a n d ~ A g r i-f o o d ~ S u p p l y ~ C h a i n ~ M a n a g e m e n t, ~ H a r p e r ~ A d a m s ~ U n i v e r s i t y, ~}$ \\ UK \\ *Corresponding Author Ademola A. Adenle ${ }^{\mathbf{1}} 108$ Johnson Dr, Fort Collins, CO 80523, United \\ States Email: ademola.adenle@colostate.edu; aadenle@gmail.com
}

\section{ABSTRACT}

Sustainable agriculture has the potential to address some of the fundamental challenges facing agricultural practices in Africa especially in Sub-Saharan Africa (SSA). The agriculture sector plays an important role as the engine of economic growth in SSA. In this paper, we ask the following key question: can sustainable agriculture save Africa from poverty and food insecurity? To address this fundamental question, we examine and critique evidence of the benefits and challenges associated with the adoption of sustainable agricultural practices in Africa. Improving agricultural sustainability is fundamental to food security and poverty reduction, particularly in achieving elements of the sustainable development goals (SDGs) by 2030, but it will not solve all these problems alone. In consort, African governments and the international community must increase their efforts in tackling problems such as conflicts, civil war, political instability, and disease. Therefore agricultural policy at the national, regional and local levels and institutional reforms must be designed to benefit food security, poverty reduction 
and income growth at the household level.

KEYWORDS: Sustainable agriculture, Challenges, Policy implication

\section{Introduction}

Increasing agricultural productivity and food security in a sustainable manner remains a huge challenge with traditional agricultural practices in Africa. ${ }^{(1)}$ Sustainable agriculture practice has an important role to play in light of growing populations, poverty, malnutrition, food insecurity and the threat of climate change. ${ }^{(2)}$ The agricultural sector in Africa is faced with multiple challenges such as insufficient access to efficient inputs, low level of-investments in the sector, restrictions related to land policy frameworks and regulations, environmental issues and climate change. Modern agricultural technologies and adoption of sustainable agricultural practices can generate socio-economic and environmental benefits. ${ }^{(2-4)}$ However, due to the increasingly prevalent challenges facing farming practices that result in low productivity and poor yields on the continent, sustainable agricultural practice is far from being realisable, especially in sub-Sahara Africa (SSA).

The strength of this study is that using a triangulation approach data is integrated from multiple sources. ${ }^{(5)}$ This approach helps to gather data, and compare and contrast information on the benefits and constraints on sustainable agricultural practices in Africa. The paper is divided into four sections. Section 1 provides an introduction and gives context to the research. Section 2 examines the importance of agriculture in terms of economic growth, food security and poverty reduction in Africa, particularly as it relates to its potential role in achieving part of sustainable 
development goals (SDGs). This section also touches on key issues related to the concept of sustainable agricultural practices in industrialized countries, while demonstrating relevant literature examples to corroborate the assertions made in the evidence-based reports. Section 3 examines the constraints that constitute a threat to the adoption of sustainable agricultural practices. Finally, Section 4 summarizes policy focus areas that can lead to sustainable agricultural development in Africa.

\section{Can sustainable agriculture save Africa from}

\section{poverty and food insecurity?}

Global food demand is projected to double over the next 50 years; and more than 800 million people including Africans are already suffering from hunger, malnutrition, poverty and challenges of sustainable food production. ${ }^{(1,6)}$ Agriculture remains as the main source of livelihood for poor people in Africa, particularly in rural areas where over $75 \%$ of its population is engaged in traditional farming practices. Agriculture in Africa drives economic development and gross domestic product (GDP) growth, industry growth, and global trade, whilst enhancing quality of life and providing jobs. ${ }^{(7)}$ The agricultural sector accounts for $32 \%$ of the GDP growth and two-thirds of employment in SSA. ${ }^{(8)}$ Yet, $40 \%$ of all Africans still go hungry, and half of SSA lives in chronic poverty on less than 1 USD a day. Binswanger and McCalla ${ }^{(8)}$ report that over the past two and a half decades, at $30 \%$, the proportion of the undernourished population in SSA has barely reduced and still remains the highest in the world (Fig. 1).

In terms of income growth, little or nothing has been achieved. Average growth in Africa 
as a whole is expected to remain moderate at $3.7 \%$ in 2016 , but could accelerate to $4.5 \%$ in 2017. ${ }^{(9)}$ This is from a low base as agricultural production per capita for the population of SSA was almost zero in the early 1970s and negative through 1980s to early 1990s. Between 1990 and 2005, agricultural growth led to hunger reduction in SSA. ${ }^{(18,19)}$ Clearly, the majority of African countries (especially SSA) struggled to achieve the Millennium Development Goal (MDG-1) of cutting hunger in half by 2015. While West African countries like Guinea, Nigeria, Ghana, Burkina Faso and Chad have experienced relatively high agricultural GDP growth (over 3.5\%) and associated poverty reduction, only Ghana was able to achieve MDG-1. It could take 520 years for other West African countries to achieve MDG-1..$^{(10,11)}$ In fact, according to a historic World Bank report "only Cape Verde, Malawi, Ghana and Ethiopia are now well-placed to achieve the majority of the MDGs, if not by 2015, then shortly afterwards". ${ }^{(12)}$ Indeed, with such limited progress the MDGs remain pertinent beyond 2015.

A study by Rippin ${ }^{(15)}$ shows how SSA countries made progression after MDG implementation (Fig. 2) where only $50 \%$ of SSA countries, met 16 accelerated enhancement out of a total of 24 indicators. Some of the main factors responsible for low agricultural productivity are shown in Fig. 3. The elaboration of sustainable development goals (SDGs) in Africa complement MDGs ${ }^{(13)}$ and build on historic progress. Although Africa has been part of the MDGs framework, historic poor performance means there is a need to develop a comprehensive approach that combines the MDGs with the SDGs that will be ultimately more efficient for Africa. ${ }^{(16)}$ Where the focus of the MDGs was on poverty reduction, the SDGs shed light on the need for a long-term, comprehensive, and sustainable development process. However, the performance of Africa in terms of the targets presented by MDGs and their completion scale is a 
starting point to realize how Africa could perform for the 2030 sustainable development agenda. $^{(14)}$

Issues related to agriculture and food are comprehensively integrated among the SDGs. Indeed there is a specific goal within the SDGs framework concerning the promotion of sustainable agriculture and achieving food security and adequate nutrition for all Africans. This goal defines some critical targets including: stopping dependency on food aid by 2030; promoting irrigation agriculture by 2025; doubling agricultural productivity by 2030 ; decreasing post-harvest losses by $75 \%$ by 2025 ; gaining zero avoidable losses by 2030 ; and doubling nutrition status by 2025. Therefore, compared to the MDGs, the food security targets in SDGs have moved from ending hunger in terms of calories to addressing wider issues of malnutrition. Moreover, the SDGs framework focuses on supply chains and food systems, enhancing productivity with sustainable and resilient implementation, and markets with decreased price volatility and revised trade limitations. ${ }^{(17)}$ Fulfilling such targets, for example, through sustainable intensification in food production and broader adoption of enhanced technologies would improve agricultural productivity and variation. Greening of the agriculture sector is required to deal with the risks related to agricultural intensification; and agricultural efficiency enhancements provide major opportunities for mitigation and adaptation of climate change, while raising agricultural productivity and tackling the issue of food and nutrition security. ${ }^{(13)}$

The definition of sustainable agriculture has a strong link with the ability of farms to produce food indefinitely while minimizing the negative impacts on health and social capital, the use of external farming inputs, and without damaging soils and ecosystems. ${ }^{(20)}$ Sustainable agriculture emphasizes multi-functional production systems within landscapes and economies: 
producing food for farming families and surplus for the markets as well as a range of valued public goods such as clean water, flood protection, carbon sequestration in soils, wild life, groundwater recharge and landscape amenity value. ${ }^{(25)}$. According to the United Kingdom's Department for International Development (DFID), ${ }^{(21)}$ the concept of agricultural sustainability goes beyond particular types of farming systems, but rather incorporates the concept of both resilience (the capacity of systems to buffer shocks and stresses) and persistence (the capacity of systems to continue over long period) and addresses the three tiers of sustainable development, namely social, economic and environmental criteria. In the context of resilience and persistence to achieve sustainable growth in agricultural production for a long period of time and beyond, countries must be able to demonstrate strong leadership, management skills, and new horizontal and vertical partnerships between institutions that reflect a high level of social and human assets. ${ }^{(6,22-24)}$ Good agriculture practice reflects the needs of rural communities and the health and safety of food products while considering local ecosystem and global environments. ${ }^{(6,23)}$ Successful agricultural sustainability is based on resource-conserving systems and integrating natural processes such as nutrient cycling, nitrogen fixing-legumes, soil regeneration, cultivations from ploughing through to zero-tillage, using natural predatory enemies of pests in food production processes, making best use of existing resources (especially water, land and biodiversity), and the use of best available technologies with less impact on the health and environment. ${ }^{(25-29)}$

While it has been often said that sustainable agriculture can offer socio-economic and environmental benefits, there are fears as to whether it might be able to meet the high demand for food in the future, particularly in Africa. There is increasing evidence ${ }^{(25,30-33)}$ that sustainable 
agriculture can lead to improved agricultural productivity compared to conventional production. A survey of 208 small scale projects between 1999 and 2000 in 52 developing countries including SSA reveals some improvement in sustainable agriculture practices. ${ }^{(25,34)}$ Burkina Faso, Uganda, Kenya, Tanzania, Malawi and Ethiopia were the African representatives for these projects. The findings showed that the adoption of sustainable agricultural practices led to improved soil fertility, improved water use efficiency, increased yields and less use of pesticides as well as improved quality of life in rural areas. For example, the efficient use of water and soil conservation methods led to the restoration of degraded land, resulting in the production of a surplus of $150 \mathrm{~kg}$ per year from annual cereal deficit of $650 \mathrm{~kg}$ in Central Burkina Faso. Adoption of soil fertility management and water harvesting technology led to improved production of millet and groundnut yield from about 300 to $900 \mathrm{~kg} / \mathrm{ha} .^{(34)}$ Reduced tillage shows higher productivity impact with increased crop revenue of \$US 106 per hectare without application of fertilizer when compared to conventional tillage. ${ }^{(32)}$

Alternatively, arguments highlight why conservation agriculture (CA) may not overcome constraints on existing low-external-input systems. CA is an approach that aims to achieve sustainable and profitable agriculture and as a result improved livelihoods of farmers through the application of the three CA principles: minimal soil disturbance, permanent soil cover and crop rotations..$^{(30,35-37)}$ However, no clear-cut empirical evidence has been provided as to which of the principles of CA contributes most to agricultural sustainability in Africa ${ }^{(36)}$ Pioneer farmers are more likely to invest in soil management (legumes, manures and terracing), but the majority of farmers are unskilled or uneducated and have little or no resources to invest in improvements. ${ }^{(38)}$ Although partial adoption of CA among small-scale farmers will be the norm, strong advocacy 
for a full adoption of CA especially with regard to its soil health benefit is still questionable. ${ }^{(30)}$

A transition to more sustainable agriculture occurs when the current need for food is met. $^{(34)}$ The impact of sustainable agriculture has led to increased production of foods that are consumed immediately with surpluses sold at local markets. Thus responsible investment in agriculture is required to tackle food security issues. Indeed, there is a significant link between poverty, hunger and agricultural productivity. In Africa if agricultural productivity increased by $10 \%$, it would reduce poverty by $7.2 \%{ }^{(40)}$ Improving soil quality ${ }^{(41)}$ and provision of seeds and other agricultural technologies that are suitable for the labor, local climate and market are necessary to implement sustainable agriculture. Agricultural innovation must improve yields, decrease environmental degradation, and be accessible to smallholders ${ }^{(40)}$ especially in SSA where yield gaps are significant and new technologies have not been sufficiently utilized. ${ }^{(12)}$ Enhanced production technologies, such as use of fertilizer rates, carefully designed plant spacing and using organic materials as nutrients will result in higher yields and increased nutrition and economic capacity. ${ }^{(42)}$ Given that MDGs/SDGs are global tools to combat food security problem, hunger and poverty crisis, more case studies need to be conducted in African countries where these tools are utilized. Further, there are many political, socio-economic, and technological constraints on sustainable development in SSA that are operating at a general, sectorial or specific foci. This is now explored further. 


\section{Constraints to sustainable agricultural development}

\section{in Africa}

\subsection{Government institutions and infrastructure}

Whilst government institutions have a basic role in the sustainable development of the agricultural sector in Africa the scene is one of fractured governance and infrastructure. Opaque national policy, weak governance and lack of social capital, remain as the most important factors constraining the advancement of sustainable agriculture. ${ }^{(43)}$ However, recent studies suggest that a few countries, such as Rwanda, are developing policies as part of an agricultural transformation agenda for sustainable agricultural practices targeting rural smallholders in the country. ${ }^{(44)}$ In a developed community, the role of government is crucial for enhancing knowledge, interplay, information-sharing, and public training, especially with regard to setting and using policies and regulations for sustainable development of agriculture. In Switzerland, government institutions are promoting sustainable agricultural practices among local communities, ${ }^{(45)}$ and agriculture projects are propelled by national support for an agricultural development policy. Switzerland has developed a national policy framework that covers the three tiers of sustainable development in agricultural practices. ${ }^{(46)}$ The Chinese government too has reformed and carefully designed an integrated program towards agricultural sustainability. ${ }^{(47,48)}$ Government support for innovation provides a context in which, various stakeholders, relationships, development policies and actions, public-private partnerships, and other institutional networks can drive a systemic sustainable agriculture approach. 


\subsection{Lack of suitable collaboration}

Common understanding, and the clarification of the principles of various actors including vulnerable smallholders, is crucial in the establishment of innovative technologies, or any notion for development of agricultural systems. The majority of the rural African population is not actively engaged in participation, discussion or debates associated with agricultural enhancement in rural societies. ${ }^{(49)}$ It is the responsibility of government institutions, mainly ministries of science and technology, and of agriculture and other related organizations at regional and national levels, to work in collaboration with local governments to directly interact with local societies. In this approach it is often the government that makes the decisions as to the kind of new technology that suits farmers and their environments often without any prior consultation with the said farmers. Uphoff ${ }^{(50)}$ suggests the role of local governments in organizing resources and adjusting their utilization is optimum. The "bottom-up" participatory approach works better and is more efficient compared to the "top-down", which starts with individual attempts and later employs higher-level assets with limited endeavors or obligations. ${ }^{(50-52)}$ There is a sense of ownership within a bottom up collaborative development of human and social capital as an approach e.g. through participatory learning and personal development as opposed to a regulatory or imposed solution where there is limited participation in the decision making process by those who have to implement the action. This A framework for local institutions based on a demand-driven strategy ${ }^{(50)}$ is used throughout Africa, but governments often fail to fulfil their responsibilities. For instance, in Kenya, existing agricultural extension services are demand-driven and need enough assets to address transport needs and other costs. However, 
extension authorities have few or no resources available. ${ }^{(53,54)}$

Effective and efficient agricultural extension plays a critical role in enhancing sustainable agricultural production, but in most African countries is significantly insufficient. ${ }^{(55)}$ The five major constraints cited by Nigerian extension authorities across five states are: 1) insufficient transport facilities; 2) low prices and lack of proper markets; 3) lack of cooperation from other agencies in program implementation; 4) lack of staff motivation and; 5) inadequate technical training in agriculture. ${ }^{(56,57)}$ Moreover, extension agents in Tanzania noted and ranked elements that prevent them from rendering sufficient and necessary training to the rural farmers. These elements include: unavailability of transportation (50\%); lack of inputs and education infrastructures (49\%); lack of research requirements and technical assistance (43\%); insufficient incentives and organizational advocacy (31\%). These sources demonstrate the major limitations for delivering appropriate extension services to rural smallholders, especially in the context of weak institutional governance. Therefore focus needs to be placed on developing mechanisms to enhance social and human capital through the use of multi-directional knowledge exchange processes rather than uni-directional knowledge transfer models that have limited benefit. This does require the development of a governance framework but the process itself once the framework is in place should recognizes the exchange element of building knowledge rather than the assumption that the superior knowledge sits outside the agricultural community. 


\subsection{Lack of entrepreneurial mind sets}

Failure to implement different soil improvement measures including cover crops, compost making, crop rotation and manure use as part sustainable agricultural techniques has been partly attributed to lack of smallholder entrepreneurship in Africa. ${ }^{(58,59)}$ The members of Montpellier Panel believe "investment in rural and food sector entrepreneurship in Africa can achieve sustainable food and nutrition security for the continent and significantly contribute to Africa's rural and urban economic growth". In Uganda, lack of interest, knowledge and appropriate training to recognize potential markets and benefits of nitrogen fertilizer use has slowed adoption. ${ }^{(58)}$ Poverty is associated with unavailability of livelihood capitals (physical, human, financial, natural and social). Thus, rural poverty can be addressed in the short term through promoting entrepreneurship and enhancing the access of people to these assets. ${ }^{(60)}$ In SSA this challenge is compounded as the number of young people is predicted to more than double from 126 million to 265 million between 2010 and $2050^{(61)}$ showing both the opportunities for, and the negative impact, if an entrepreneurial mindset is not widely adopted. This requires policy development and investment so governments, private sectors and donors need to provide opportunities for growth by strongly supporting, accelerating and encouraging participation and engagement 


\subsection{Lack of suitable infrastructure}

For many decades, the unavailability of well-constructed and equipped infrastructure and the impact on service availability such as extension, credit, market data and health care has been a major constraint for agricultural and rural development in Africa. ${ }^{(7)}$ Weak communication, irrigation, transportation and supply facilities within various African countries is not helping sustainable development of the agricultural sector. Access to information can accelerate sustainable agricultural development, through marketing networks and efficient management of post-harvest activities. ${ }^{(62,63)}$ Roads are clearly a critical enabling condition for reducing poverty, improving living conditions and productivity in rural areas providing accessing to markets, or providing a connection to related production/services for particular centers. ${ }^{(64)}$

Irrigation can contribute significantly to poverty alleviation, food security, and improving the quality of life for rural population. However, the use of irrigation is dependent on effective sustainable water resources management. Inadequate rainfall in many African countries, means farming activities can be challenging as the soils become very hard to cultivate. Irrigation may be very costly for smallholders who often do not have the financial resources to adopt these practices.

Credit plays an important role in agricultural development and the expansion of credit programmes will have beneficial effects on agricultural production and the incomes of poor farmers alleviating poverty, allowing livelihood diversification, and increasing the business skills of the farmers. ${ }^{(65)}$ Furthermore due to the lack of access to credit facilities, farmers cannot pay the costs for enhanced agricultural inputs such as seeds and fertilizers. Micro-credit systems that 
could assist rural farmers in meeting their financial needs are limited and not broadly developed. Indeed, even if they exist, they are generally not sufficient, stable or reliable.

\subsection{Land use system and linkage between land tenure, food security and sustainable agriculture}

Land use evolution in Africa has been gradually transformed from straightforward hunting through to more complicated, uncontrolled, commercial cultivation system. Land use patterns in rural areas have shifted from bush hunting in tropical regions of Africa such as Kalahari Desert. Additionally, pastoralist activities and pygmies groups in the Zaire/Congo Basins have undergone changing cultivation that has widely occurred in the woodlands of Miombo in SSA where vegetation and soil can be fallowed earlier than the time needed for enrichment and preparation for next cultivations. ${ }^{(66)}$ The current land tenure challenges have resulted from the administrative and resource rights systems developed over the colonial period security. ${ }^{(67)}$ Therefore, an understanding of the land use systems and the transformation processes African countries have undergone as a result of colonialism is important in order to find the linkages between land tenure, food security and sustainable agriculture. For instance, the colonial age saw the emergence of the semi-permanent hoe and ox-plough cultivation that has developed among the Luvale, Lozi and Mambwe peoples. Among the Lozi and Mambwe, cattle raising offers an opportunity for ox-drawn ploughing which in turn facilitates the expansion of cultivated areas. Soil fertility is maintained by application of cattle manure. These indigenous

semi-permanent agronomic systems were first identified by Trapnell and Clothier. ${ }^{(68)}$ Indeed, through such domestic agronomic activities and limited use of agricultural technology, 
sustainable arable production meets food security in these rural areas.

A unique feature of colonialism in Africa is that it defined land as a communal and customary possession. Thus, the customary tenure is related to both personal relations (marriage, succession, movement) and access to productive resources (land). Colonialism in Africa was followed by the creation of 'land markets' of various types. These provide a platform within which land is disposed of between private people (natural or corporate), without recourse to state bodies, except for the purposes of registration and notification of the transactions. Thus, transactions in the land market are not absolutely 'free' as the state administrative structures retain intermediatory functions through the land registry, land administrative courts and other entities that prescribe such land transactions. In redistribution programs of land, different land market approaches have been created including 'Willing seller-willing buyer'; 'Market assisted' land reforms; 'Market led' land reforms; and 'State led' market based processes. However, land markets also vary with regard to different land regulatory processes, like land use directives, land taxation, rules related to land sizes and environmental management implementation. Also, relationships between access to land and land tenure are critical where communities rely on land to secure their food security. ${ }^{(67)}$ Land degradation due to soil erosion, nutrition depletion, pollution, overgrazing and deforestation have become major issues in African agriculture. Where there is no pressure or competition over traditional land use systems, through adaption and using slopes within a traditional system, for example, fallow, wood lots and pasture ${ }^{(69)}$ and plant coverage like crops and mulches will provide efficient conservation agriculture that is resistant to erosion. ${ }^{(70)}$ In Zambia and Ethiopia, for example, the procedure of land acquisition for farming practices was regulated. ${ }^{(71,72)}$ Since several African countries have become politically 
independent and the population has increased, the utilization of technological innovations has increased as a result of the emergence of commercial farming. ${ }^{(73)}$ At the same time, more traditional agricultural implementation developed, and consequently, the British declaration of the land tenure regulation system shifted and modified to deal with the cultural, social, economic and political changes in those countries. ${ }^{(74)}$ Having equal access to land is important to the sustainable management of land and can be beneficial for poorer communities. Urbanization results in more pressure on the customary land tenure system in many African countries. As a result of increasing value, agricultural land close to urban areas is being transformed through urban constructions either through official permissions or unofficially. Thus farmers near to urban areas can simply lose their farmland. ${ }^{(76)(78)}$

Given that decreasing the fallow area has resulted in a major decline in food production amidst growing population pressure means that traditional African agricultural activities are still required. Moreover, the current land tenure system severely restricts the implementation of sustainable practice. Improvements in agricultural productivity and food security as well as enhancing financial support and promoting appropriate management of natural resource are of limited value due to the current insecurity in the land tenure system and the unavailability of formal documentation for land use rights. In northern Ethiopia, insecure land tenure remains an important factor affecting investment in soil conservation practices and tree planting. In many countries in Africa, national policies for land development and economic growth are not in accordance with agricultural activities, especially within the rural areas. For example, the rights of women (that represent the majority of agricultural labor in SAA) with regards to land are poorly developed, often ignored and marginalized. Therefore, it is important to recognize how 
existing land tenure systems intensively restrict sustainable agricultural implementations in SSA.

The dominant land tenure system in SSA is the customary land tenure i.e. the land is common property and must not be subjected to sale or to other means of exchange. ${ }^{(77)}$ Issues with land allocation in SSA from community to individual ownership, resulting from urbanization and growing demands for peri-urban land e.g. in Accra, Ghana, ${ }^{(78)}$ have three main interconnected concerns: (1) lack of good management of urban lands, (2) inadequate infrastructure, and (3) tenure insecurity. There is, therefore, a need to give context to the urbanization processes of land under customary land tenure in peri-urban Africa and understand the problems that arise. ${ }^{(78)}$

The indiscriminate allocation of land is another major issue and is becoming alarming in Africa. Rich countries (especially China) are coming to Africa to grab lands, particularly in SSA, in the guise of helping to build the local economy. ${ }^{(79)}$ For example, Chinese companies are known to have acquired lands in East and Southern Africa. Wuhan Kaidi, a power company, has negotiated a seemingly undisclosed deal over land acquisition for jatropha cultivation (biofuel production) in Zambia. ${ }^{\left({ }^{80}\right)}$ There has been a deal for 1.3 million hectares of land between the South Korean company (Daewoo Logistics) and the government of Madagascar. A key part of the deal was to grow maize and oil palm in the west and east of the country mainly for exporting to South Korea. However, this was officially cancelled following a change of government in Madagascar. ${ }^{(81,82)}$ Arab countries like Qatar and Saudi Arabia are also actors in land grabbing. For example, $\$ 400$ million have been invested into food production in Sudan and Ethiopia by a consortium of Saudi Agricultural firm called Jenat, having previously invested in 10,000 hectares of wheat, barley and livestock in Egypt. ${ }^{(83,84)}$ Whilst land in Africa is abundant with $60 \%$ of the world's uncultivated arable land, poor management and indiscriminate land grabs can force 
indigenous people off their customary lands, unavoidably affecting their methods of sustainable agricultural production. Nevertheless, the increase in the number of international land deals is raising global concern about land as a scarce resource in Africa. While in the past, Western countries and organizations invested in agriculture mainly in order to find comparative opportunities in their production for the world market, to date land deals are increasingly resulting from the willingness to secure rights to land and water for the energy requirements and domestic food needs of the particular investor. ${ }^{(85)}$ In Tanzania, women's land ownership and user rights are negatively affected by land grabbing. Similarly in Ghana, where women do have user rights according to the customary tenure law to cultivate cash crops like cocoa, shea and oil palms, land grabs adversely impact women their livelihoods. Formal long-term leases for large land areas have also been the common way of granting land to foreign and national investors. ${ }^{\left({ }^{86}\right)}$

In SSA, there have often been limitations on land transactions as well, either as part of the customary tenure system or under statutory law, but there has been a wider trend toward policies that put fewer constraints on such land transactions. The nature of the policies that are legitimized is an important issue in SSA, where access to land is such an important basis for the livelihoods of many. The lack of identifying customary land rights in statutory law is a major threat to tenure, thus governance concerns will have to be addressed before land markets in SSA can play a more favorable, enabling role in delivering the SDGs. In many countries, land or any private property under the ownership of governments needs to be known as part of an agreement under the countries law. For instance, United States law requires that there will be recompense if the state acquires private assets and Brazil and the Philippine constitution also require money to be provided as compensation. The constitution of Cambodia enforces that the state governments 
of the country make equal and fair compensation when taking lands from any individual. ${ }^{(87)}$ In comparison to such approaches, land loss or private properties acquired by governments in Africa is usually not financially compensated. Although the enhancement of payment can be mandatory in most of African countries, it is generally not enough and not timely. ${ }^{(88,89,90)}$ Interventions by Land Commissions, such as the compulsory acquisition of land and nonpayment of compensation, has resulted in social unrest, displacement of villagers, and landlessness in affected communities. ${ }^{(90)}$ However, no compensation or annual rental payments have ever been made to the communities affected by the government approach in Ghana. Taking property and land from rural people without any payment can be more destructive and intensive in other countries in Africa, especially where poorer and vulnerable groups have less political power. For example, in 2005, in Zimbabwe, approximately one quarter of a million people lost their properties because they had established illegal markets and business activity close to the capital Harare and other urban areas. The compulsory acquisition of land by the government was without compensation, causing those affected to live in hardship. ${ }^{(91)}$ This remains one of the major problems in the land use system in Africa, and limited investment in sustainable land management can result in low productivity of land and food security problems on the continent. ${ }^{(92)}$ 


\subsection{Urbanization}

\subsubsection{Land degradation}

Whilst the rural population in Africa has increased by $265 \%$, the population in urban areas has increased nine times more during a fifty year period between 1950 and 2000. ${ }^{(94)}$ Industrialization and migration from rural to urban areas can improve agricultural salaries and enhance the demand for modern agricultural technologies. ${ }^{(99)}$ Rural-urban migration has affected agricultural labor availability and rural social life as the young population migrates to urban areas, seeking better jobs and life. Reduced labor productivity in rural regions is a motivation for establishing labor-saving systems, encompassing agro-chemicals that improve labor productivity but can also bring vulnerabilities to water and land resources if inappropriate technologies are adopted. Moreover, poorer smallholder families that cannot easily afford labor-saving technologies will encounter even more serious issues unless there are some mechanisms that make restitution, such as microcredit and labor-sharing.

Cultivated agricultural lands has expanded due to the significant dependency of the rural poor as a result of population pressure on domestic agriculture for their subsistence. ${ }^{(95)}$ Urbanization, through population migration, has had an impact on food demand as well as driving the shift in diets and demand. ${ }^{(93)}$ Often, the land occupation in urban areas with no appropriate legal formation of land ownership is a major constraint for innovation, occupation and economy opportunities throughout the city. Urbanization has influenced the type of crops, the way that the crops are cultivated and the sustainability of production technologies. Increased urban competition over accessibility to natural resources leads to resource degradation, in both 
urban and rural areas. It is estimated that land degradation causes a 3\% reduction in African agriculture GDP per year. ${ }^{(96)}$ Thus, a considerable increase in productivity is needed through intensifying cultivation in order to enhance food supplies on less resources. ${ }^{(85)}$ Expanding cultivation within vulnerable landscapes and improper intensification implementation are the major drivers for resource degradation. Land degradation has become one of the main concerns in Africa as it has influenced approximately 2 billion hectares of land with 300 million hectares experiencing substantial nutrient loss, soil erosion and desertification. ${ }^{(97,98)}$ Soil erosion and nutrient loss are fundamental driving forces of land degradation. In Uganda, six main farming and agro-ecological zones have been influenced by soil reduction with an average loss of 179 $\mathrm{kg} / \mathrm{ha}$ of phosphorus $(\mathrm{P})$, nitrogen $(\mathrm{N})$ and potassium $(\mathrm{K})$ each year equal to nearly $1.2 \%$ of the nutrient stock supplied in the topsoil $\left(0-20 \mathrm{~cm}\right.$ depth). ${ }^{(97)}$

\subsubsection{Growing demands for agricultural products}

In humid regions of Africa, the high urban demand for maize has contributed at least in part to maize replacing sorghum and millet in the savannah regions of SSA. ${ }^{(85)}$ In regions where such a crop shift is occurring, the new demand-induced crops usually have distinct production needs that mainly result in land degradation and vulnerability to climatic variables. Fig. 4 shows that the World Bank anticipates that urban food markets in Africa will increase fourfold by 2030, to exceed $\$ 500$ billion, assuming that the value of food consumption per capita is $25 \%$ higher in urban areas than in rural areas, ${ }^{(12)}$ thus leading to suggestions that world food production may need to grow by $70 \%$ by 2050 in comparison to 2005 . Many SSA agriculture economies have experienced structural change as a result of such rapid development in urban food markets. ${ }^{(100)}$ 
These markets not only try to expand the cropland boundaries into the rural areas, but also as a result of the dynamic national, regional and local markets, lead a rapid change in the agriculture sector.

Despite continuous food imports, the major needs for food consumption of urban populations in Africa are provided by local agriculture. Urban population growth and variety in city diets generates high demand for future agricultural subsectors in Africa. Recent surveys show that rural people as well as those living in urban areas are increasingly using urban markets to provide for their food requirements. Even smallholders are turning to the markets to sell their crops and to buy food. In spite of such market dynamism, food crop sectors are generally poorly organized in Africa. The weak infrastructure of food distribution, transportation and marketing systems for delivering food to urban markets are further barriers. ${ }^{(85)}$ In Africa, there are many incompetencies and service failures in supply and delivery channels for urban areas. Retailers and wholesale markets are usually not well structured or managed. Moreover, market facilities are outdated, poorly kept and are not large enough to meet the increased demand of growing population. ${ }^{(85)}$ All these factors result in the undermining of rural agriculture capacity to meet the growing demand of urban consumers for agricultural commodities. SSA needs investment in agriculture and agribusiness to ensure efficient and sustainable agricultural production, ${ }^{(100)}$ and challenges remain in terms of infrastructure, trade, skills and financing. However, there is increasing commitment from governments and other partners for a food sector with strong, resilient, growth opportunities. 


\subsection{Climate change}

Based on the fifth assessment report of the Intergovernmental Panel on Climate Change (IPCC), Africa is the most susceptible continent to climate change despite its minimal contribution to the growing greenhouse gas concentrations. ${ }^{(101)}$ In particular, SSA is vulnerable to climate change because of low amounts of physical and human capitals, large levels of poverty, poor facilities and infrastructure and SSA's dependency on sectors that are very sensitive to climatic variations such as rain-fed agriculture. ${ }^{(101,102)}$ Also, SSA is one of the most negatively affected areas in the world due to its high exposure to climate change effects, and because widespread poverty intensively constrains its potential to cope (mitigate or adapt). Moreover, evidence suggests that climate change will influence the sensitive transformation of economic procedures and exacerbate food insecurity in Africa and increase severe hazards. ${ }^{(101,102)}$ These authors argue that climate change will have a great impact on water, food and energy production, biodiversity, poverty reduction and economic growth where the agricultural sector plays a prominent role.

A growing body of literature has documented the possible impact of climate change on sustainable agriculture in Africa as well as describing some of the events that are associated with the adverse effect of global warming. ${ }^{(37,101-111)}$ Africa is one of the major regions of the world that is significantly exposed to global warming considering the fact that $40 \%$ of its people are living in arid, semi-arid, or dry areas. ${ }^{(111)}$ During the past century, this continent has experienced about a $0.7^{\circ} \mathrm{C}$ increase in temperature while it is expected to experience between $0.2^{\circ} \mathrm{C}$ and $0.5^{\circ} \mathrm{C}$ additional increase in temperature in every decade. As advanced tools for measurement 
have emerged, the decrease in rainfall detected in the Sahel is seen as the most significant and stable record in the world. ${ }^{(105)}$ The number of hydro-meteorological disasters including extreme temperature, from large to small scale country level, continue to provide an indication of a changing climate. ${ }^{(104)}$ In Table 1 , analysis of natural hazard incidence and its effects at the regional level in 2010 demonstrates that Africa experienced rather more extreme events $(n=69)$ in comparison with the annual average disaster incidence over the last decade. This was mainly because of increased number of hydrological events (resulted from variation in the regular water cycle or overflow of water bodies). On average, other natural hazards happened less and as a result, $82.6 \%$ of disasters were related to hydrological hazards in 2010, whereas from 2000 to 2009, the share was $66.5 \%$ among all natural hazards occurred in Africa.

Attempts to deal with supply shocks from the increasing demand for water and food will be adversely influenced by a wide variety of stresses, such as higher temperatures, shifting rainfall patterns, increasing sea levels, desertification and drought. An estimated 14.4 million people were in need of assistance due to a food deficit of 13.3 million tonnes caused by drought in Southern Africa in the year 2002-2003. ${ }^{(12)}$ In the year 2005, the combined effects of severe drought led to shortage of food across different African countries, including Malawi, Ethiopia, Eritrea, Zambia, Sudan, Niger and Zimbabwe. ${ }^{(37,109,110)}$ The horrific effect of drought and desertification led to the starvation of young children, hundreds of thousands of human deaths, and millions of animal deaths ${ }^{(113)}$ showing the high risk of reduction in crop and livestock yields due to climate change. ${ }^{(101,108)}$ The impact of climate change in Africa is estimated to be considerably more adverse than predictions in developed countries, but less alarming than developing countries like India and Mexico. ${ }^{(8)}$ Around 230 million Africans are projected to 
suffer from water scarcity and 460 million expected to live in water-stressed countries (14 African countries are already suffering from water-stress situations) by the year $2025 .{ }^{(114,94)}$ The impact of drought and desertification on the energy sector will also affect hydro-power for electricity generation in Africa (Table 2$)^{(116)}$. Ghana experienced a fall in water level (below the minimum level of 250 feet) at the Akosombo dam that led to reduction of hydro-power electricity generation in 2007. ${ }^{(115)}$ Other African countries have experienced drought in the past that affected hydro-power generation (Table 2). ${ }^{(116)}$ Climate variability after 2000 shows a decoupling of the relationship between GDP and rainfall for economic conditions ${ }^{(117)}$ particularly in Ethiopia with a relatively low agricultural productivity and contribution to GDP.

Global analysis on the impact of climate change on agriculture reveals that SSA will be one of most affected regions ${ }^{(102,118)}$ as stated below:

- In a no-climate change scenario, only SSA (of the 6 regional groupings of developing countries studied in the report) sees an increase in the number of malnourished children between 2000 and 2050, from 33 to 42 million. Climate change will further increase this number by over 10 million, resulting in 52 million malnourished children in 2050.

- Additional investments to increase agricultural productivity can compensate for many of the adverse effects of climate change. SSA needs 40 percent of the estimated $\$ 7$ billion per annum in additional global agricultural investments. The majority of that figure is required for rural roads.

- The crop model indicates that in 2050 in SSA, average rice, wheat, and maize yields will decline by up to 14 percent, 22 percent, and 5 percent, respectively, as a result of climate change. 
- Reliability of irrigation water storage, the amount of water usage needed is predicted to become more severe in SSA because of climate change.

- Without climate change, calorie availability is expected to increase in SSA between 2000 and 2050. With climate change, however, food availability in the region will average 500 calories less per person in 2050, a 21 percent decline, and

- Unless maize breeding system improves and adapts, climate change will reduce the yields of this crop drastically.

Concerns regarding climate change and biodiversity are mutually interrelated. ${ }^{(103)}$ Observed patterns of warming and their changes over time, are simulated by models that include anthropogenic forcing. By 2020, significant loss of biodiversity is projected to occur in some ecologically rich sites as a result of increasing global mean temperature. ${ }^{(106)}$ Global ecosystem change is currently undermining species and habitats and will lead to further reductions in biodiversity, ecosystem function and its consistency. ${ }^{(107)}$ Added to this, the Millennium Ecosystem Assessment (MEA) suggests that biodiversity loss can have significant direct human health impacts if ecosystem services are no longer adequate to meet social needs. Indirectly, changes in ecosystem services affect livelihoods, income, local migration and, on occasion, may even cause political conflict (Fig. 5).

Political instability, especially, in the Horn of Africa is a threat to sustainable agriculture and food security. 


\subsection{Political and social instability}

The cost of a typical civil war to the country and its neighbors is around $\$ 64$ billion, reflecting the economic impact of frequent civil wars. ${ }^{(119)}$ Civil war, especially in countries dependent on oil, diamond and other natural resources, represents a big obstacle to practicing sustainable agriculture. Civil wars are said to reduce growth on average by $2.3 \%$ on and sharply increase disease incidence. In addition to these factors, death and sicknesses resulting from pandemics of HIV/AIDS, malaria, cholera and TB have led to a reduction of the household labor force, particularly that of women, who represent almost $50 \%$ of agricultural labor in SSA, ${ }^{(120)}$ This too can have a great impact on agricultural productivity. Moreover, lack of a competitive environment and lack of access to global markets for agricultural products in Africa are major indicators of limited economic growth and rural development in African countries. It is usually difficult for farmers in Africa to meet the quality standard needed for exporting their products due to unavailability of the skills to expand money in marketing, asset and processing infrastructures that can deliver to international food standards and protocols. Due to market failures such as insufficient transport facilities, insufficient general infrastructure, poor institutional arrangements, low prices and the lack of proper markets, most private sectors as demonstrated in Tanzania are not willing to invest in highly limited mechanized farming systems. ${ }^{(121)}$ Such situations put private sectors within an undesirable and widely non-influential situation in the international marketing system. ${ }^{(122,123)}$ In Malawi, low agricultural productivity is understood as one of the major constraints in agribusiness and market development (highlighted by farmer organizations and stakeholders). 


\subsection{Summary}

Taken together, all these factors represent a significant problem in African agriculture. Furthermore, sustainable agriculture will be very difficult to practice, which may worsen the current problem of hunger and malnutrition and food insecurity. The factors outlined in this paper should be taken into account in decision-making processes on developing strategies, policies and priorities in research and development. ${ }^{(39)}$ Government focus and appropriate governance measures are essential to ensure the adoption of sustainable agricultural practices and innovative technologies in Africa.

\section{Conclusion}

In view of the fact that the issues examined reflect the fundamental aspect of agricultural development and the challenges associated with sustainable agriculture practices in SSA and as the need to tackle these challenges becomes more imperative, African governments, developed countries, multilateral institutions and other relevant stakeholders must increase their coordinated efforts that will nor only favour agricultural sustainability in Africa but also the achievement of the SDGs and beyond. Resource prioritization for both food and energy security, aligned with national government policies, will facilitate much needed climate change adaption and mitigation in SAA. Given the lack of existing quantitative risk and environmental impact assessments, future studies should quantify the return on investment, in terms of economic, social and environmental outputs that are associated with the adoption of new sustainable agricultural technologies in SSA. Improving agricultural sustainability is fundamental to food 
security and poverty reduction, but it will not solve all these problems alone and increasing efforts to tackle problems such as conflict, civil war, political instability, diseases and others is essential. It is the holistic combination of well-designed strategies and policies that will pave the way for sustainable agricultural development in Africa.

\section{References}

1. 2009. How to Feed the World in 2050. http://www.fao.org/fileadmin/templates/wsfs/docs/expert_paper/How_to_Feed_the_World_in_2 050.pdf. Accessed December 2015.

2. Lal, R., 2008. Soils and sustainable agriculture. A review. Agronomy for Sustainable Development 28, 57-64.

3. Adenle, A.A., Azadi, H., Arbiol, J., 2015. Global assessment of technological innovation for climate change adaptation and mitigation in developing world. Journal of Environmental Management 161, 261-275.

4. Arslan, A., McCarthy, N., Lipper, L., Asfaw, S., Cattaneo, A., 2014. Adoption and intensity of adoption of conservation farming practices in Zambia. Agriculture, Ecosystems \& Environment 187, 72-86.

5. Denzin, N., 2006. Sociological methods: a sourcebook. Aldine Transaction.

6. Tilman, D., Cassman, K.G., Matson, P.A., Naylor, R., Polasky, S., 2002. Agricultural sustainability and intensive production practices. Nature 418, 671-677.

7. Rudi, L.M., Azadi, H., Witlox, F. 2012. Reconcilability of socio-economic development enhancement and environmental improvement in the context of Sub-Saharan Africa. Global and 
Planetary Change, 86-87, 1-10.

8. Binswanger, M.H., McCalla, A.F., 2010. The Changing Context and Prospects for Agricultural and Rural Development in Africa. Handbooks of Agricultural Economics. 4, 35733706.

9. AEO (The African Economic Outlook). 2016. Sustainable Cities and Structural Transformation.

http://www.afdb.org/fileadmin/uploads/afdb/Documents/Publications/AEO_2016_Report_Full_ English.pdf

10. Nin-Pratt, A., Johnson, M., Magalhaes, E., You, L., Diao, X., Chamberlin, J., 2011. Yield Gaps and Potential Agricultural Growth in West and Central Africa. International Food Policy Research Institute. Washington, D.C.

11. UNDP, 2015. United Nations Development Programme. The Millennium Development Goals Report 2015.

12. WB-IMF, 2011. World Bank- International Monetary Fund. Annual Meeting. Washington D.C.

13. United Nations Economic Commission for Africa. 2015. Economic Report on Africa 2015. http://www.uneca.org/publications/economic-report-africa-2015

14. Bianchi, S. 2015. DEVELOPMENT: EU Seen as Vital to MDGs. http://www.ipsnews.net/2005/01/development-eu-seen-as-vital-to-mdgs/

15. Rippin, N., 2013. Progress, Prospects and Lessons from the MDGs.Background research paper submitted to the High Level Panel on the Post-2015 Development Agenda. German Development Institute. Available at: http://www.post2015hlp.org/wp- 
content/uploads/2013/05/Rippin_Progress-Prospects-and-Lessons-from-the-MDGs.pdf.

16. Simelane, T., Chiroro, B. 2013. Beyond the Millennium Development Goals: What can Africa expect? Africa Institute of South Africa, Briefing No. 84.

17. Weitz, N., Nilsson, M., Davis, M. 2014. A nexus approach to the post-2015 agenda: formulating integrated water, energy and food SDGs. SaIS Review of International affairs, $34: 37-50$.

18. Juma, C., 2011. The New Harvest. Agricultural Innovation in Africa. Oxford University Press.

19. Pingali, P., Stamoulis, K., Anriquez, G., 2007. Poverty, Hunger, and Agriculture in Subsaharan Africa; Opportunities and Challenges. Presentation at the OECD, FAO, World Bank, IFAD Global Forum on Agriculture, Rome, November 12-13.

20. UNCTAD-UNEP, 2008. Organic Agriculture and Food Security in Africa. United Nations Conference on Trade and Development United Nations Environment Programme (UNCTAD-UNEP).

21. DFID, 2004. Agricultural Sustainability. Department for International Development (DFID). Working Paper. London. UK.

22. Chambers, R., Pacey, A., Thrupp, L.A., 1989. (eds). Farmer first: farmer innovation and agricultural research. London, UK: Intermediate Technology Publications.

23. Jordan, N., Boody, G., Broussard, W., Glover, J.D., Keeney, D., McCown, B.H., McIsaac, G., Muller, M., Murray, H., Neal, J., Pansing, C., Turner, R.E., Warner, K., Wyse, D., 2007. Sustainable Development of the Agricultural Bio-Economy. Science 316, 1570-1571.

24. Pretty, J., Ward, H., 2001. Social capital and the enviroment. World Development 29. 
25. Pretty, J.N., Morison, J.I.L., Hine, R.E., 2003. Reducing food poverty by increasing agricultural sustainability in developing countries. Agriculture, Ecosystems \& Enviroment 90, 213-234.

26. Conway, G., 1999. The Doubly Green Revolution: Food for All in the 21st Century. Penguin Books, London; Cornell University Press, Ithaca, NY.

27. Giller, K.E., Cadisch, G., 1995. Future benefits from biological nitrogen-fixation-an ecological approach to agriculture. Plant Soil 174, 255-277.

28. Pretty, J.N., 1995. Renegrating Agriculture. Policies and Practice for Sustainability and Self-reliance. Earthscan Publications.

29. Uphoff, N., 2002. (Ed.) Agroecological Innovations:Increasing Food Production with Participatory Development. Earthscan, London.

30. Gowing, J.W., Palmer, M., 2007. Sustainable agricultural development in sub-Saharan Africa: the case for a paradigm shift in land husbandry. Soil Use and Management. doi: 10.1111/j.1475-2743.2007.00137.x.

31. Graves, A., Matthews, R., Waldie, K., 2004. Low external input technologies for livelihood improvement in subsistence agriculture. Advances in Agronomy, 82, 473-555.

32. Kassie, M., Pender, J., Yesufa, M., Kohlin, G., Bulffstone, R., Mulugeta, E., 2007. Estimating Returns to Soil Conservation Adoption in the Northern Ethiopian Highlands. Agricultural Economics, 38:213-232.

33. Pretty, J.N., Noble, A.D., Bossio, D., Dixon, J., Hine, R.E., Penning de Vries, F.W.T., Morison, J.I.L., 2006. Resource-Conserving Agriculture Increases Yields in Developing Countries. Environ. Sci. Technol., 2006, 40 (4), pp 1114-1119. 
34. Pretty, J., 2008. Agricultural sustainability: concepts, principles and evidence. Philosophical Transactions of the Royal Society B: Biological Sciences 363, 447-465.

35. Pittelkow, C.M., Liang, X., Linquist, B.A., van Groenigen, K.J., Lee, J., Lundy, M.E., van Gestel, N., Six, J., Venterea, R.T., van Kessel, C., 2015. Productivity limits and potentials of the principles of conservation agriculture. Nature 517, 365-368.

36. Giller, K.E., Witter, E., Corbeels, M., Tittonell, P., 2009. Conservation agriculture and smallholder farming in Africa. The heretics' view. Field Crops Research 114, 23-34.

37. FAO, 2005. www.fao.org (on food security and climate change- section on desertification and food security).

38. Crowley, E., Carter, S., 2000. 'Agrarian change and the changing relationships between toil and soil in Maragoli, Western Kenya (1900-1994)', Human Ecology, 28, pp. 383-414.

39. UN. 2012. The United Nations Development Strategy Beyond 2015. http://www.un.org/en/development/desa/policy/cdp/cdp_publications/2012cdppolicynote.pdf

40. Braun, A., Jiggins, J., Röling, N., van den Berg, H., Snijders, P. 2005. A global survey and review of Farmer Field School experiences. Nairobi: International Livestock Research Institute.

41. Oyetunji, O.I., Ekanakaye, I.J., Osonubi, O. 2001. Influence of yam fungi on cassavamaize intercrop in an alley cropping system. Proceedings of African Crop Science Conference, Uganda. 5:1079-1083.

42. Urama, K.C., Ozor, N., Kane, O., Hassan, M., 2010. Sub-Saharan Africa, chapter 14, UNESCO Science Report 2010, 279-321.

43. Collier, P., Gunning, J.W., 1999. Explaining African economy performance. Journal of 
Economic Literature. 37:64-111.

44. Dawson, N., Martin, A., Sikor, T., 2016. Green Revolution in Sub-Saharan Africa: Implications of Imposed Innovation for the Wellbeing of Rural Smallholders. World Development 78, 204-218.

45. Aerni, P., 2009. What is sustainable agriculture? Emperical evidence of diverging views in Switzerland and New Zealand. Ecological Economics 68, 1872-1882.

46. Saefl. 2000. Swiss Agency for Environment Forests and Landscape and Federal Office of Agriculture. Swiss on its way to sustainability. Basel.

47. Lei, Y., Liu, C., Zhang, L., Luo, S., 2016. How smallholder farmers adapt to agricultural drought in a changing climate: A case study in southern China. Land Use Policy 55, 300-308.

48. Li, W., 2001. Agro-ecological Farming Systems in China, Man and the Biosphere Series, Vol 26. UNESCO, Paris.

49. Handley, G., Higgins, K., Sharma, B., Bird, K., Cammack, D. 2009. Poverty and poverty reduction in Sub-Saharan Africa: An overview of the issues. Working London: Overseas Development Institute, P. 299.

50. Uphoff, N., 1986. Local Institutional Development: An Analytical Sourcebook, with Cases. Kumarian Press, West Hartford, CN.

51. Nordhaus, T., Shelenberger, M., 2007. Break Through: From Death of Environmentalism to the Polictics of Possibility. Houghton Miflin Company, New York.

52. Prins, G., Rayner, S., 2007. Time to Ditch Kyoto. Commentary. Nature 449, 973-975.

53. KSP, 2005. Kenya Ministry of Agriculture. Ministry of Agriculture Strategic Plan. 20052009. 
54. KSRA, 2004. Republic of Kenya. Strategy for Revatilising Agriculture in Kenya (20042014). Ministry of Agriculture, Livestock and Fisheries Department.

55. Azadi, H., Filson, G., 2009. Comparative study of agricultural extension systems: A systemic view.

Outlook on Agriculture<http://www.ingentaconnect.com/content/ip/ooa/2009/00000038/00000004/art00006 $\geq, 38(4), 337-347$.

56. Dimelu, M.U., Salifu, E.D., Igbokwe, E.M., 2016. Resource use conflict in agrarian communities, management and challenges: A case of farmer-herdsmen conflict in Kogi State, Nigeria. Journal of Rural Studies 46, 147-154.

57. Nigel, R., 1989. Agricultural Extension in Afriea; A World Bank Symposium. World Bank, Washington, DC. Descriptive Report 141.

58. Andersson, E., 2015. Turning waste into value: using human urine to enrich soils for sustainable food production in Uganda. Journal of Cleaner Production 96, 290-298.

59. Becx, G.A., Mol, G., Eenhoorn, J.W., van der Kamp, J., van Vliet, J., 2012. Perceptions on reducing constraints for smallholder entrepreneurship in Africa: the case of soil fertility in Northern Ghana. Current Opinion in Environmental Sustainability 4, 489-496.

60. Guidi, D. 2011. Sustainable Agriculture Enterprise: Framing Strategies to Support Smallholder Inclusive Value Chains for Rural Poverty Alleviation. Centre for Internal Development at Harvard Working Paper No. 53.

61. Brooks, K., Zorya, S., Gautam, A., Goyal, A. 2013. Agriculture as a Sector of Opportunity for Young People in Africa. Policy Research Working Paper \# 6473, Washington DC: World Bank. 
62. Bertolini, R., 2004. Making information and communication work for food security in Africa. 2020 Africa Conference Brief 11. International Food Policy Research Institute: Washington DC.

63. Poole, N.D., Kenny, L., 2003. Agricultural market knowledge:System for delivery of a private and public good. Journal of Agricultural Education and Extension, 9. 117.126.

64. Oraboune, S. 2008. Infrastructure (Rural Road) Development and Poverty Alleviation in Lao PDR. Institute of Developing Economies, JETRO. http://www.ide.go.jp/English/Publish/Download/Dp/pdf/151.pdf

65. Poliquit, L. Y. 2006. ACCESSIBILITY OF RURAL CREDIT AMONG SMALL FARMERS IN THE PHILIPPINES. Master thesis of Applied Science in Rural Development, Institute of Natural Resources. http://mro.massey.ac.nz/bitstream/handle/10179/1687/02_whole.pdf

66. Pritchard, J.M., 1979. Africa: A Study Geography for Advanced Students, Longman Group, Revised Third Edition.

67. Jayne, T.S., Chamberlin, J., Headey, D.D., 2014. Land pressures, the evolution of farming systems, and development strategies in Africa: A synthesis. Food Policy 48, 1-17.

68. Trapnell, C.G., Clothier, J.N., 1996. The Soils, Vegetation and Traditional Agriculture of Zambia, Volume 1(Central and Western Zambia Ecological Survey 1932-1936); and Volume 2 (by Trapnell, North Eastern Zambia, Ecological Survery 1937-1942).

69. Clay, D.C., Lewis, L.A., 1990. Land Use, Soil Loss and Sustainable Agriculture in Rwanda. Human Ecology, 18 (2), pp.147-161.

70. Wischmeier, W.H., Smith, D.D., 1978. Predicting Rainfall Erosion Losses, A Guide to 
Conservation Planning, Agricultural Handbook No 537. USDA, Washington, D.C. pp.1-58.

71. Gilks, P., 1975. The Dying Lion: Feudalism and Modernization in Ethiopia. Julian Friedmann Publishing Ltd, London.

72. White, C.M.N., 1959. A Preliminary Survey of Luvale Rural Economy. The RhodesLivingstone Papers No 29, Manchester University Press.

73. Baylies, C., 1979. The emergence of indigenous capitalist agriculture: the case of Southern Province, Zambia in Rural-Africana, 4-5, Spring-Fall, pp 65-81.

74. Mvunga, M.P., 1980. The Colonial Foundations of Zambia Land Tenure System. NECZAM, Lusaka.

75. UN-HABITAT, 2003. United nations human settlements programme (UN-HABITAT). The challenge of slums: global report on human settlements 2003. London: Earthscan.

76. Benjaminsen, T., Sjaastad, E., 2002. Race for the prize; land transaction and rent appropriation in the Malian Cotton Zone. European Journal of Development Research 14 (2), $129-152$.

77. Fisher, R. 1993. Tensions and Tenures in Post-Apartheid South Africa. December 1993 International Land Tenure Conference. Royal Institute of Chartered Surveyors and the University of East London.

78. Mends, T. 2006. A study on the Customary Land Tenure System and its Impact on Urbanization. Case Study: The Peri-Urban Area of Accra, Ghana. MSc. Thesis ITC Netherlands

79. Azadi, H., Houshyar, E., Zarafshani, K., Hosseininia, G., Witlox, F., 2013. Agricultural outsourcing: A two-headed coin? Global and Planetary Change, 100, 20-27.

80. LT, 2009. Lusaka Times (LT):Interview with Biofuels Association of Zambia, 14 April. 
81. BBC, 2009. "Madagascar Leader Axes Land Deal", 19 March, http://news.bbc.co.uk/go/pr/fr/-/1/hi/world/africa/7952628.stm.

82. Jung-a, S., Olivier, C., Burgis, T., 2008. "Madagascar Farms Lease - Daewoo to Pay Nothing for Vast Land Acquisition”, Financial Times, 20 November.

83. Reuters, 2008. "Soaring Food Prices to Spur Agriculture Investment", 2 July, http://uk.reuters.com/article/gc08/idUKL0245321820080702?pageNumber=2\& virtualBrandChannel $=0$.

84. Reuters, 2009. "Saudi firm in $\$ 400$ million farm investment in Africa", 15 April. http://af.reuters.com/article/investingNews/idAFJOE53E02F20090415.

85. UN. 2004. United Nations: World Urbanisation Prospects: the 2003 Revision, United Nations Population Division, Department of Economics and Social Affairs, ST/ESA/SER.A/237, New Yorks, 323 pp.

86. Deininger, K., Byerlee, D. 2011. The Rise of Large Farms in Land Abundant Countries: Do They Have a Future? World Development, Vol. 40, 4, 701-14.

87. ECV, 2011. Exploration, Compensation and Valuation: ADB Policy and International Experience. (http://www.adb.org/Documents/Reports/Capacity-Building-CompensationValuation/chap1.pdf) Access 25 August, 2011.

88. Benjaminsen, T., Sjaastad, E., 2008. Legal Empowerment for Local Resource Control: Securing Local Resource Rights within Foreign Investment Projects in Africa, London. IIED.

89. Cotula, L., 2008. Legal Empowerment for Local Resource Control: Securing Local Resource Rights within Foreign Investment Projects in Africa, London. IIED.

90. Kasanga, K., Kotey, N.A., 2001. Land Management in Ghana. Bulding on Tradition and 
Modernity. IIED London.

91. de Plessis, J., 2005. The growing problem of forced evictions and the crucial importance of community-based, locally appropriate altenatives. Enviroment and Urbanisation 17(1), 123134.

92. Nyanga, A., Kessler, A., Tenge, A., 2016. Key socio-economic factors influencing sustainable land management investments in the West Usambara Highlands, Tanzania. Land Use Policy 51, 260-266.

93. Azadi, H., Ho, P., Hasfiati, L., 2011. Agricultural land conversion drivers: A comparison between less developed, developing and developed countries. Land Degradation \& Development, $22,596-604$.

94. UNCCD, 2004. Ten years on: UN marks World Day to Combat Desertification; Observances worldwide on June 17, 2004.

95. Wood, A., Stedman-Edward, P., Mang, J., 2000. Root Causes of Biodiversity Loss. Earthscan Publications.

96. Jansky, L., Chandran, R., 2004. Climate change and sustainable land management: Focus on erosive land degradation. Journal of the World Association of Soil and Water Conservation 4: $17-29$.

97. Nkonya, E., Pender, J., Kaizzi, K.C., Edward Kato, Mugarura, S., Ssali, H., Muwonge, J., 2008. Linkages between Land Management, Land Degradation, and Poverty in Sub-Saharan Africa. The Case of Uganda. International Food Policy Research Institute. Research Report 159. 98. Pintstrup-Anderson, P., Pandya-lorch, R., 1995. Food security and the enviroment. Ecodecision 18:18:22. 
99. Satterthwaite, D. 2010. The Role of Cities in Sustainable Development. http://www.bu.edu/pardee/files/2010/04/UNsdkp004fsingle.pdf

100. Schaffnit-Chatterjee. 2014. Agricultural Value Chains in Sub Saharan Africa. From a Development Challenge to a Business Opportunity. Current Issues: Emerging Markets. Deusche Bank Research. Germany. Retrieved from http://www.dresearch. com on 23/2/2014.

101. Carabine, E., Lemma, A., Dupar, M., Jones, L., Mulugetta, Y., 2014. What's in it for Africa? The Intergovernmental Panel on Climate Change (IPCC). The Fifth Assessment Report. 102. Nelson, G.C., Rosegrant, M.W., Koo, J., Robertson, R., Sulser, T., Zhu, T., Ringler, C., Msangi, S., Palazzo, A., Batka, M., Magalhaes, M., Valmonte-Santos, R., Ewing, M., Lee, D., 2009. Climate Change: Impact on Agriculture and Costs of Adaptation. International Food Policy Research Institute (IFPR).

103. CBD, 2009. Convention on Biological Diversity- CBD. Connecting Biodiversity and Climate Change Mitigation and Adaptation: Report of the Second Ad Hoc Technical Expert Group on Biodiversity and Climate Change. Montreal, Technical Series No. 41, 126 pages.

104. Guha-Sapir, D., Vos, F., Below, R., Ponserre, S., 2011. Annual Disaster Statistical Review 2010: The Numbers and Trends. Brussels: CRED.

105. Hulme, M., Kelly, P.M., 1993. Exploring the linkages between climate change and desertification. Environment 35, 4-11.

106. IPCC, 2007. Climate change 2007. Synthesis report. Contributions of Working Groups I, Ii, and Iii to the Fourth Assessment Report of the Intergovermental Panel on Climate Change. Geneva: IPCC.

107. Isbell, F., 2010. Causes and Consequences of Biodiversity Declines. Nature Education 
Knowledge 1(11):17.

108. Lobel, D.B., Burke, M.B., Tebaldi, C., Mastrandrea, M.D., Falcon, W.P., Naylor, R.L., 2008. Prioritizing climate change adaptation needs for food security in 2030. Science, 319: 607610.

109. Nhambura, F., 2006. Africa must address food security; The Herald, (Zimbabwe) 14 February 2006; http://www.herald.co.zw/inside.aspx?sectid=448\&cat=10.

110. Radford, T., Vidal, J., 2005. One in six countries facing food shortage; in The Guardian; Thursday June 30, 2005; http://www.guardian.co.uk/climatechange/story/article_continue.

111. UNDP, 1997. Aridity zones and dryland populations: an assessment of population levels in the world's drylands with particular reference to Africa. UNDP Office to Combat Desertification and Drought (UNSO), New York.

112. Andrew, S., 2005. Africa - Up in smoke? The second report from the Working Group on Climate Change and Development. nef(the new economics foundation).

113. McHarry, J., Scott, F., Green, J., 2002. Towards Global Food Security: Fighting against hunger. Towards Earth Summit 2002, Social Briefing \#4 http://www.earthsummit2002.org/es/issues/foodsecurity/foodsecurity.rtf.

114. SH, 2011. Drought: http://www.solcomhouse.com/drought.htm.

115. PSEC, 2010. Power Systems Energy Consulting (PSEC). Ghana Wholesale Power Reliability Assessment. Final Report. http://www.gridcogh.com/site/downloads/27a623e256c7d94a7dce43d5ef82d3e3GridCoReportFi nal.pdf.

116. AFREPREN. 2005. African Energy Policy Research Network (AFREPREN). Making the 
African Power Sector Sustainable. Final Regional Report.

117. Conway, D., Persechino, A., 2008. Technical Assessment of Indicators Used forContingency Financing Mechanisms in Ethiopia. University of East Anglia,Overseas Development Group, 34 pp.

118. Challinor, A.J., Koehler, A.K., Ramirez-Villegas, J., Whitfield, S., Das, B., 2016. Current warming will reduce yields unless maize breeding and seed systems adapt immediately. Nature Clim. Change advance online publication.

119. Collier, P., 2007. The Bottom Billion: Why the Poorest Countries are Failing and What Can Be Done About It. Oxford: Oxford University Press.

120. FAO, 2011. The role of women in agriculture. The Food and Agricultural Organisation of United Nations. EAS Working Paper No. 11-02.

121. Ponte, S., 2001. Policy reforms, market failure and input use in African smallholder agriculture. European Journal of Development Research 13(1):1-29.

122. Allen, J., Thompson, G., 1997. Think global, then think again- Economic globalisation in context. Area 29:213-27.

123. Stiglitz, J., 2003. Globalisation and its discontent. W.W. Norton, New York. 
Table 1. Analysis on natural disaster incidence and impacts at regional level, adapted from Guha-Sapir et al. ${ }^{(104)}$.

\begin{tabular}{|c|c|c|c|c|}
\hline Number of Natural Disaster & Africa & Global & $\begin{array}{l}\text { Africa's } \\
\text { percentag }\end{array}$ & Global \\
\hline Climatological 2010 & 6 & 50 & 12 & \\
\hline Avg. 2000-9 & 9 & 54 & 16 & \\
\hline Geophysical 2010 & 1 & 31 & & \\
\hline Avg. 2000-9 & 3 & 31 & & \\
\hline Hydrological 2010 & 57 & & 26 & \\
\hline Avg. 2000-9 & 43 & & 22 & \\
\hline Meteorological 2010 & & 88 & 5.7 & \\
\hline Avg. 2000-9 & & 105 & 8.6 & \\
\hline Total 2010 & & 385 & 18 & \\
\hline Avg. 2000-9 & 64 & 387 & 16.5 & \\
\hline
\end{tabular}


Table 2. Impact of drought on hydropower generation in SSA, adapted from AFREPREN ${ }^{(116)}$.

\section{Country}

Periods

Uganda in $2004 / 05$

Kenya 1992

Kenya

$1998-2001$

Lesotho 1992

Malawi

$1997-1998$

Mauritius

1999

1997

Tanzania

Zambia

1992

\section{Drought impact}

Reduction in water levels at Lake Victoria resulting in reduction hydro-power generation by $50 \mathrm{MW}$

Failure of rains led to power rationing in April-May 1992

Massive drought decreased hydro generation $(25 \%$ in 2000), which had to be replaced by more expensive fuelbased generation power rationing in 1999-2001

Hydro operation limited to 6 months, leading to $20 \%$ reduction compared to 1991

Engineering operations affected by drought. Amount of hydro energy generated was 6 percent less than in years of normal rainfall

Massive drought led to $70 \%$ drop in normal annual production of electricity

The Mtera dam reached its lowest ever level resulting in a $17 \%$ drop in hydro generation, use of thermal generation to meet the shortfall, and power rationing Poor rainfall resulted in a $35 \%$ reduction in hydro generation in relation to the previous year 
Zimbabwe 1993

compared
Drought led to a drop of over $9 \%$ in energy production to 1992

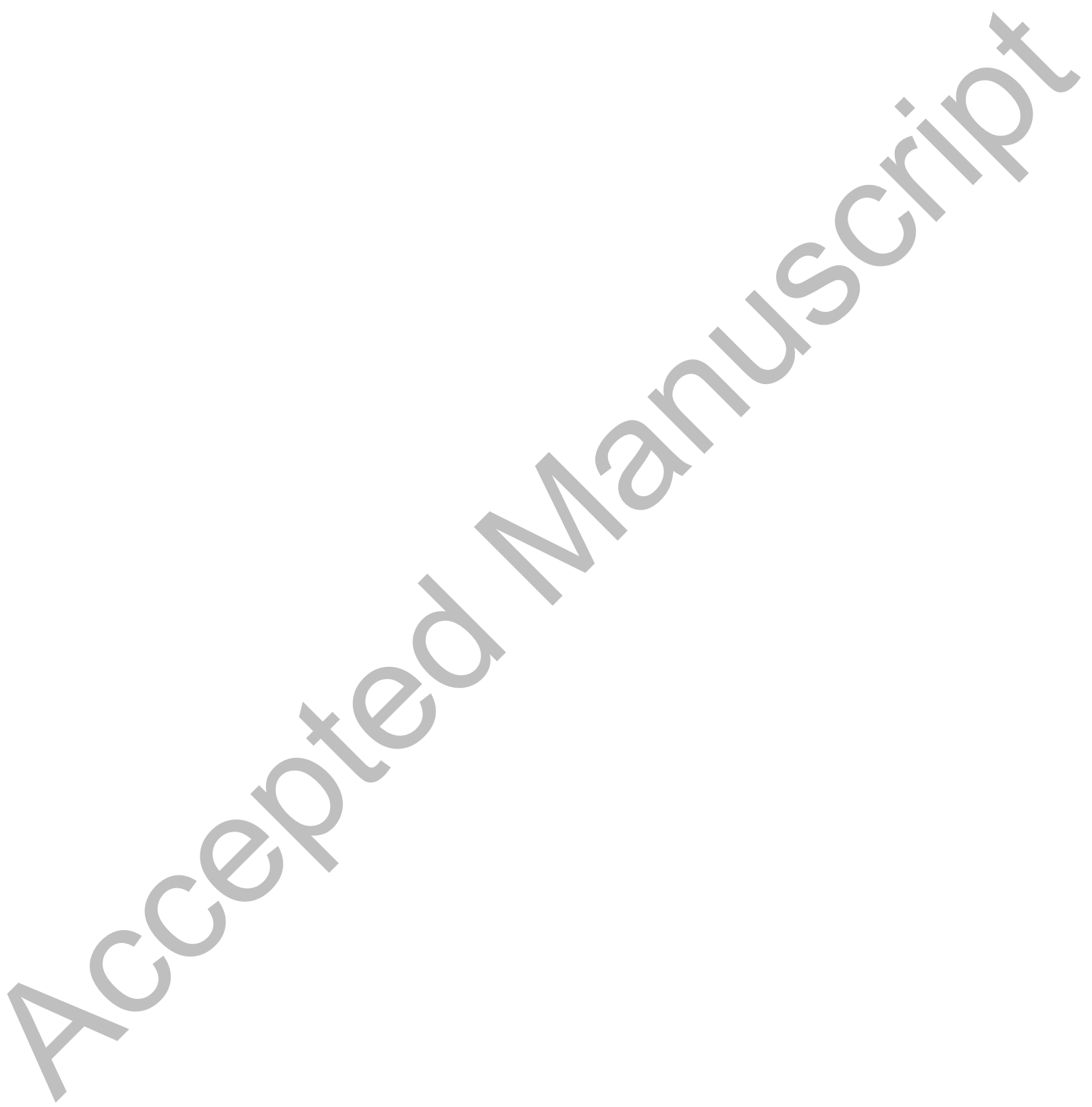


Fig. 1. SSA as the most affected region with prevalence of hunger, adopted from Binswanger and $\mathrm{McCalla}^{(8)}$.

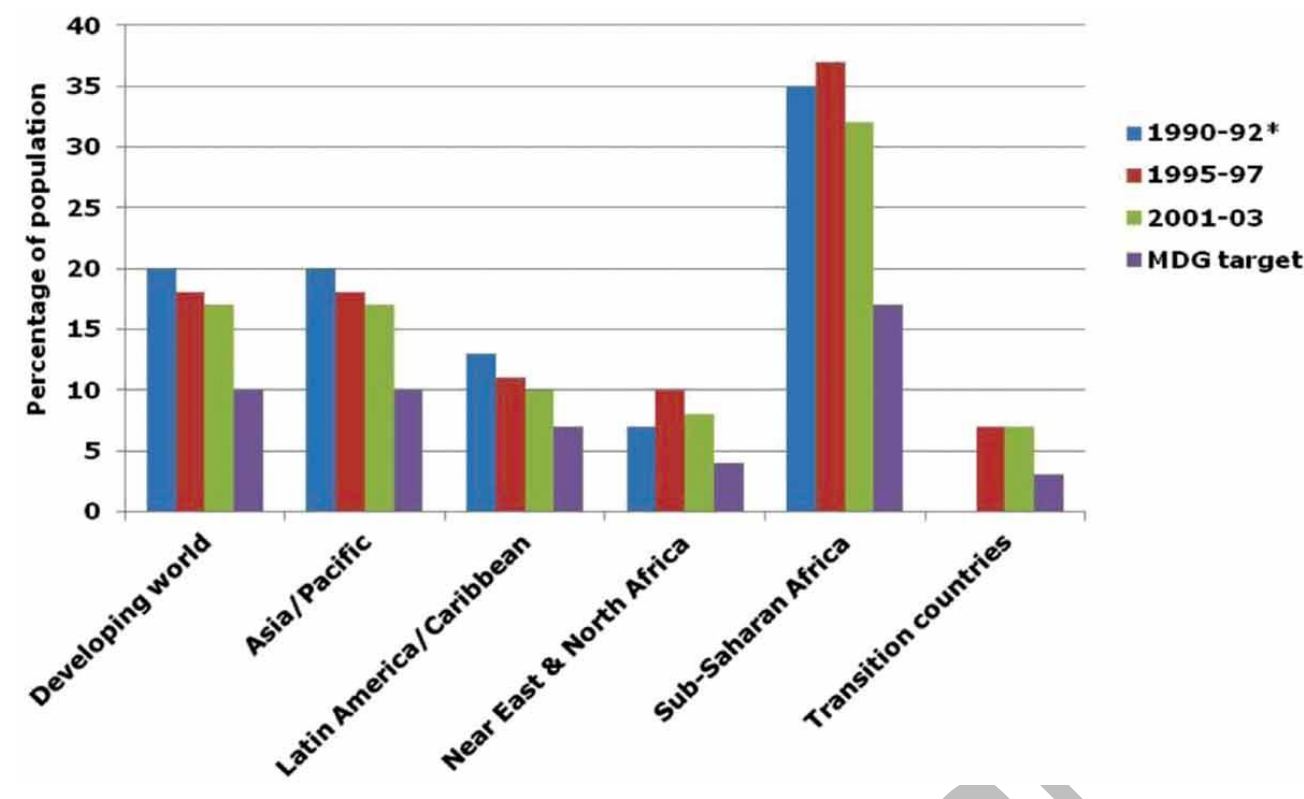


Fig. 2. Percentage of accelerated progress for SSA countries after MDG implementation, adopted from Rippin ${ }^{(15)}$.

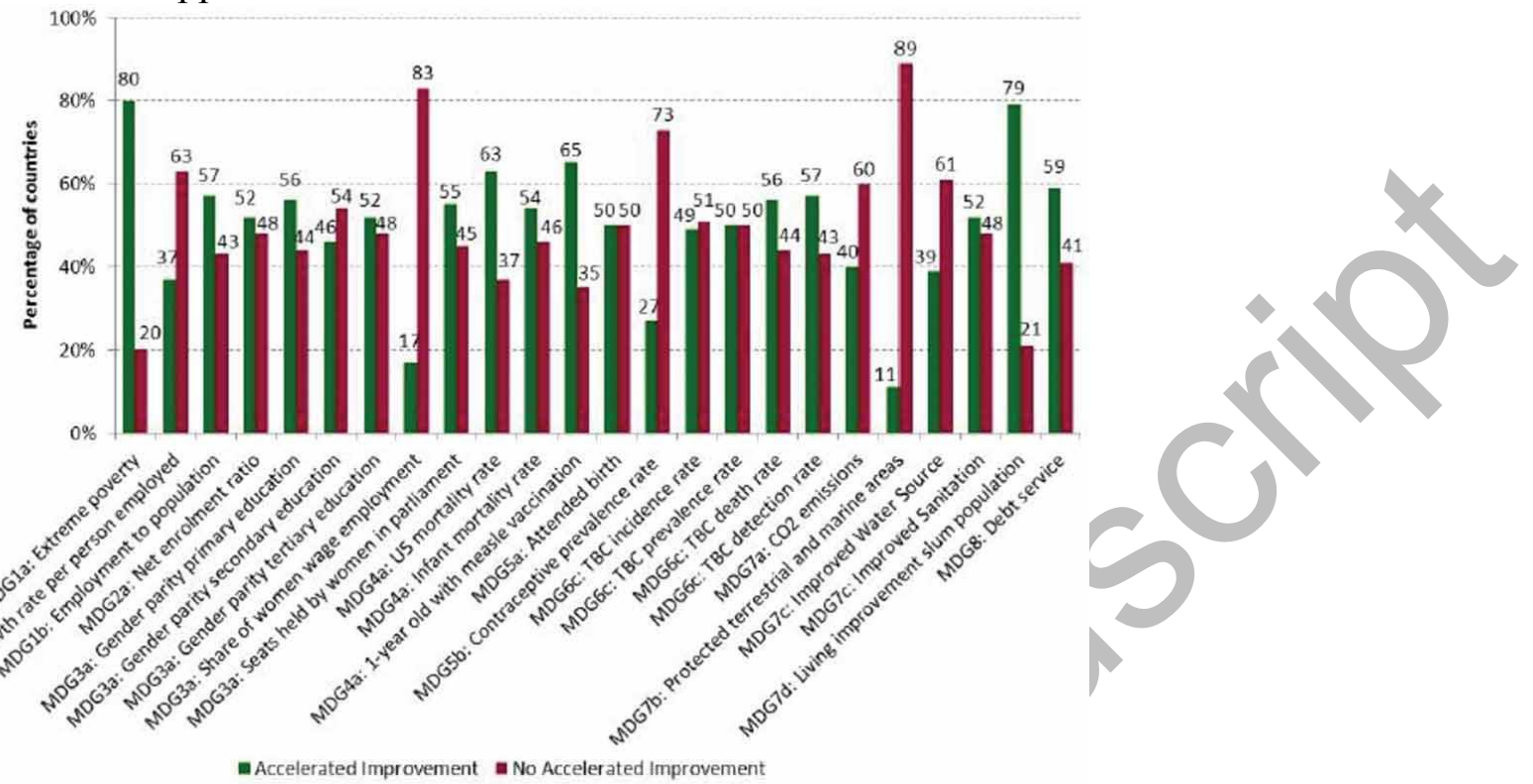


Fig. 3. Factors responsible for low agricultural productivity in SSA.

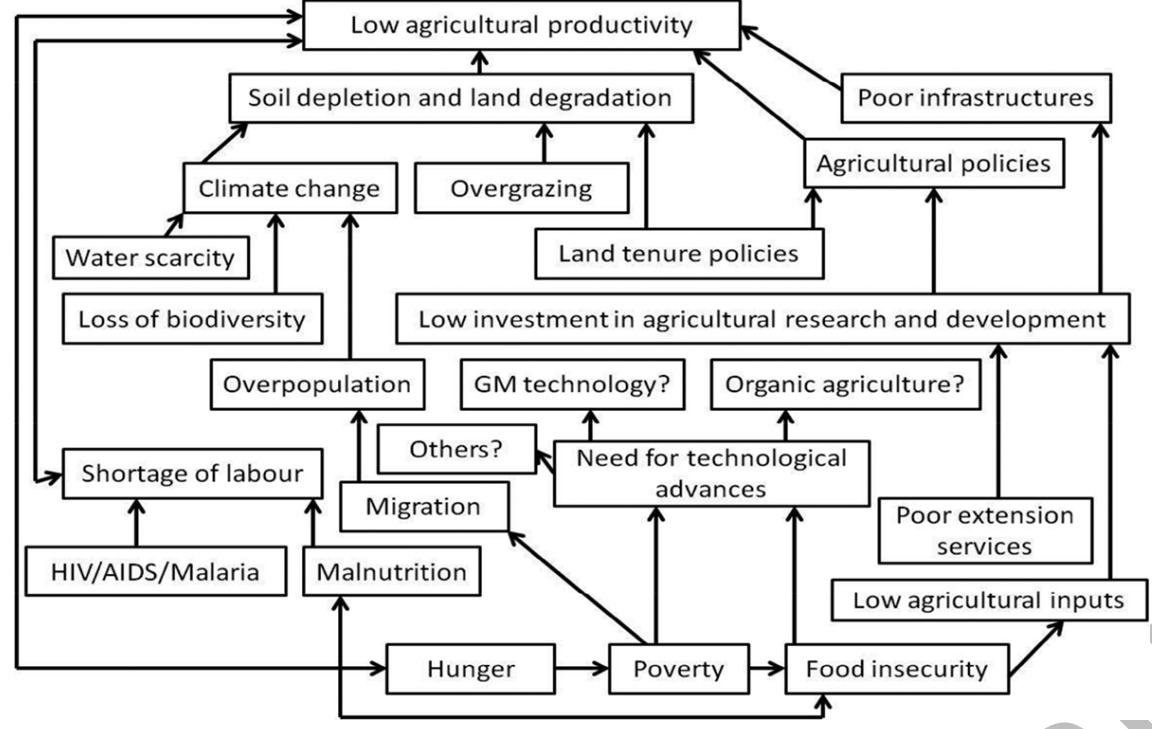


Fig. 4. Food markets to treble by 2030, adapted from Schaffnit-Chatterjee ${ }^{(100)}$ Value of SSA food markets, USD, billion

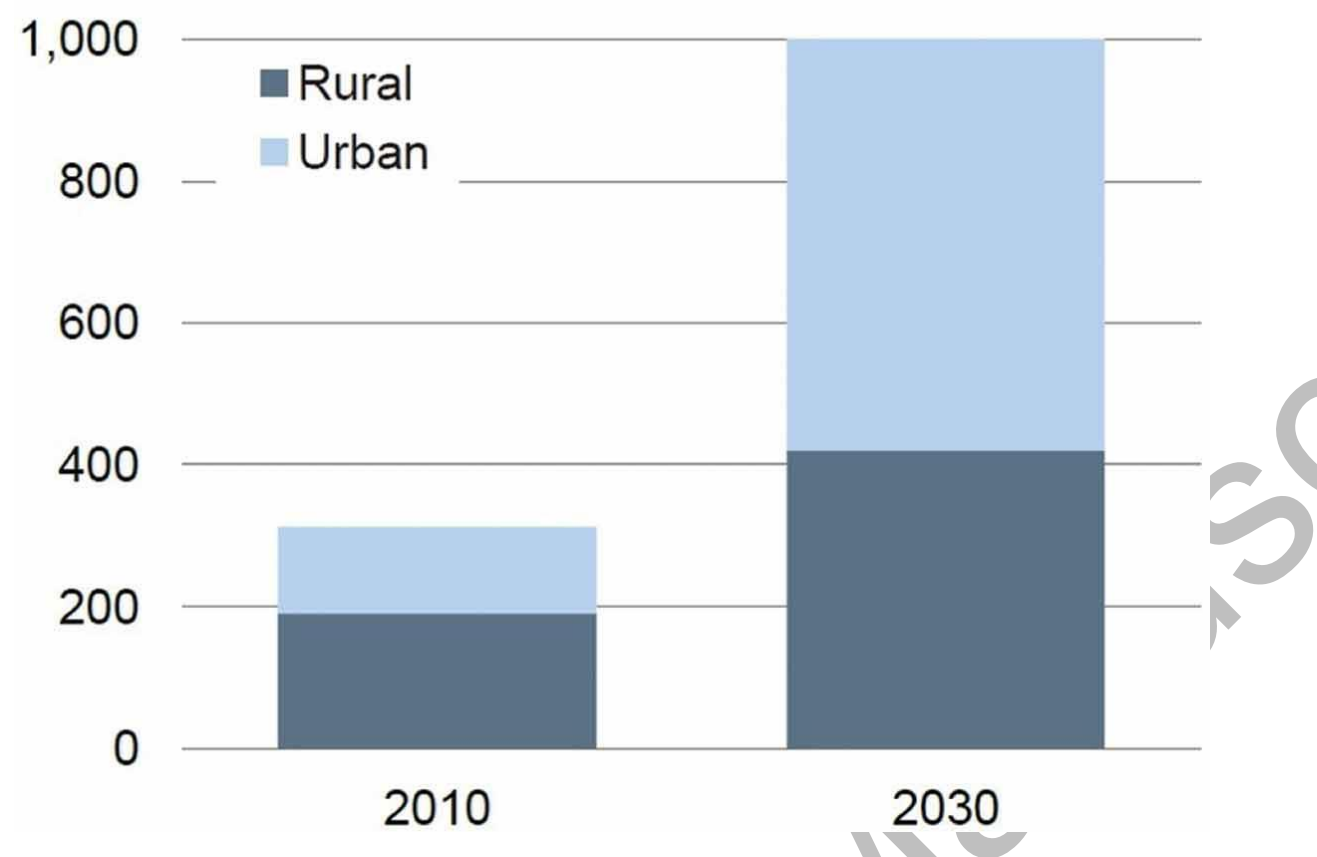


Fig. 5. A comparative image showing the relationship between poverty, human well-being and ecosystem services, adapted from MA (Millennium Ecosystem Assessment) (2005).

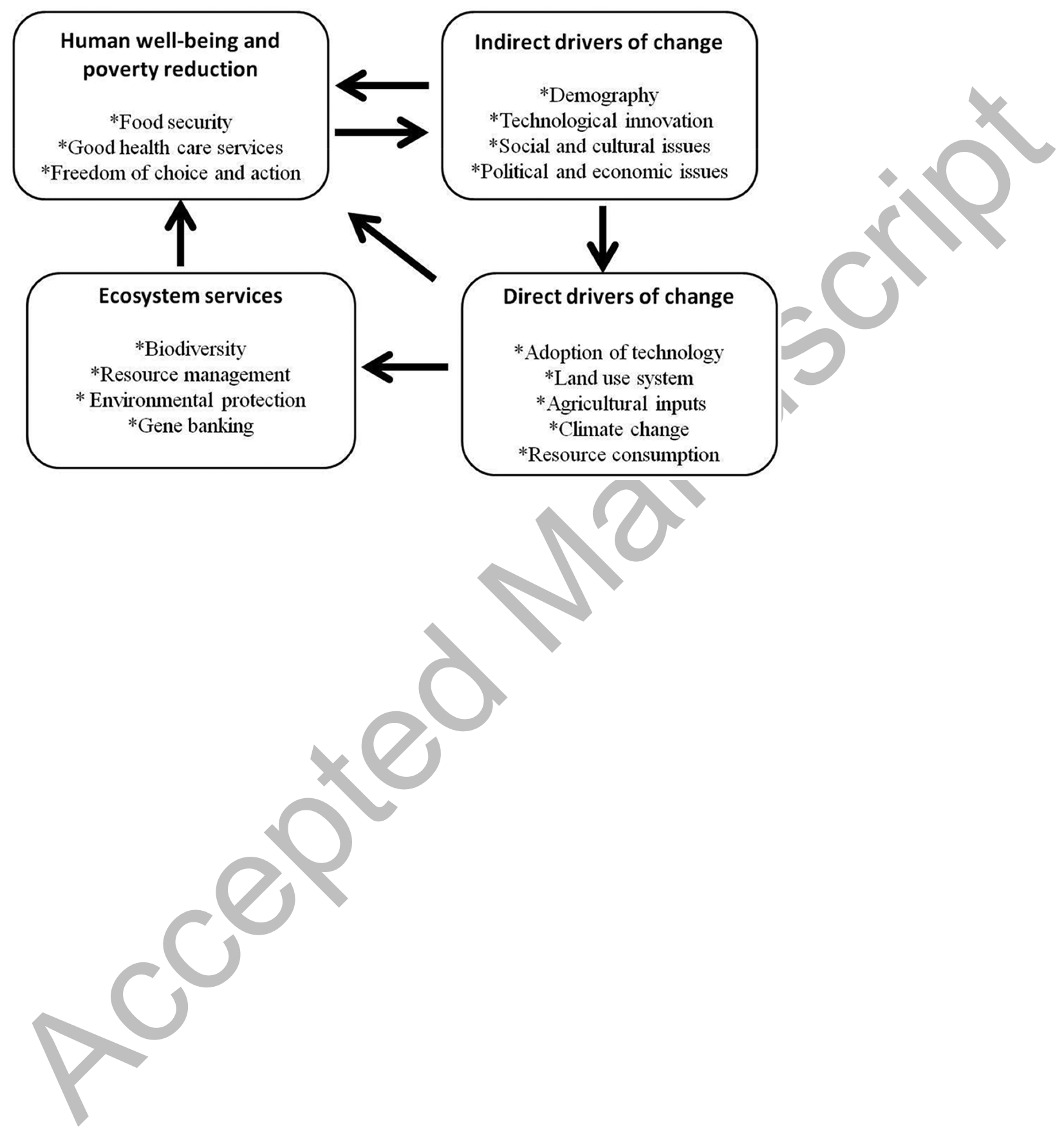

